\title{
Molecular Characterization and Phylogenetic Analysis of Full-length S1 Gene of GI-16 and GI-23 Infectious Bronchitis Virus in Qena, Egypt
}

\author{
Mahmoud Sabra, Wesal Abdellatif, Ahmed Ibrahim Ahmed and Nabila Osman* \\ Department of Poultry Diseases, Faculty of Veterinary Medicine, South Valley University, Qena, 83523, Egypt \\ *Corresponding author's Email: nabila.osman@vet.svu.edu.eg; ORCID: 0000-0002-0176-0349
}

Received: 22 Jan. 2020

Accepted: 28 Feb. 2020

\begin{abstract}
Infectious Bronchitis Virus (IBV) is a highly evolving virus that affects respiratory, urinary and reproductive systems. This virus is recognized as an important pathogen due to the continuous genesis of new variants that threaten the poultry industry worldwide. The aim of this study was to characterize emerging IBV variants originated from field outbreaks in Qena province, Egypt, and to study their genetic relationships with global strains. From September 2017 to January 2019, 52 field samples were collected from broiler flocks suspected of being infected with IBV. The collected samples were inoculated into embryonated chicken eggs via allantoic route for virus isolation. The IBV presence was confirmed using real-time reverse transcriptase PCR (rRT-PCR) assay targeting nucleocapsid (N) gene and finally, nine samples were selected from 29 positive samples with rRT-PCR for further genetic characterization through full-length spike (S1) gene sequencing. Phylogenetic analyses indicated that one isolate (IBV/CK/EG/QENA-4/2017) clustered within genotype I lineage 16 (GI-16). On the other hand, the remaining eight isolates (2017-2018) belonged to genotype I lineage 23 (GI-23) and clustered separately in monophyletic clade. The isolates in this study were found to share only 74.6-82.1\% amino acid identity with the commonly used vaccine strains in Egypt. In conclusion, findings of this study provide informative data on circulating IBVs in the study area and highlight the importance of adopting a convenient vaccination strategy that can be more efficient for controlling the emergence of new IBV variants.
\end{abstract}

Key words: Full-length spike gene, GI-16, GI-23, Infectious bronchitis virus, Phylogenetic, RT-PCR.

\section{INTRODUCTION}

Avian infectious bronchitis (IB) is a highly contagious acute viral disease of chickens that is of great economic importance in the poultry industry. This disease is caused by Infectious Bronchitis Virus (IBV) and the upper respiratory tract is considered the main site for virus replication (Raj and Jones, 1997; Jackwood and de Wit, 2013). However, some IBV strains have also a great affinity to replicate in the reproductive tract and the kidneys, as well as some other strains have been reported to replicate in other tissue such as proventriculus (Yu et al., 2001).

IBV is a member of genus Gammacoronavirus within family Coronaviridae. The virus has a positive sense, enveloped, single-stranded and non-segmented RNA genome (Boursnell et al., 1987; Cavanagh, 2007), consisting of regions that code for four structural proteins including the nucleocapsid protein $(\mathrm{N})$, the membrane glycoprotein (M), the envelope protein (E), and the spike glycoprotein (S). It also includes regions $1 \mathrm{a}$ and $1 \mathrm{ab}$ expressing the replicase gene, in addition to that it comprises several accessory regions (Spaan et al., 1988; Masters, 2006; Jackwood and de Wit, 2013). The N gene is highly conserved even among IBV isolates of different serotypes, therefore, it is often chosen as the target gene for virus detection by real-time reverse transcriptase PCR (rRT-PCR) assay (Meir et al., 2010; Bande et al., 2016).

After translation, the $\mathrm{S}$ glycoprotein is cleaved into two subunits, S1 and S2 (Perlman and Netland, 2009). The S1 subunit encloses not only in the infectivity of the virus but also contains virus neutralization and serotype-specific epitopes which are located in three different Hyper Variable Regions (HVRs). These epitopes are responsible for the induction of neutralizing antibodies and immune responses (Cavanagh et al., 1988; Moore et al., 1997). The nucleotide sequence variation in the S1 gene may lead to lower cross-protection against serotypes and can modify the protection ability of a vaccine or immunity (Cavanagh and Gelb, 2008). Therefore, the nucleotide sequence of S1 
gene is used to classify IBV strains and to identify new IBV variants that may challenge vaccination protocols (De Wit et al., 2011; Valastro et al., 2016). Recently, Valastro et al. (2016) proposed a unified IBV classification system based on S1 phylogeny that divided IBV strains into six main genotypes from GI to GVI comprising 32 viral lineages.

IBV was first documented in Egypt by Ahmed (1954) and since then, several IBV strains with continuous diversity and recombination have been reported (AbdelMoneim et al., 2006; Zanaty et al., 2016). The majority of IBV strains circulating in Egypt especially in the last years clustered into two distinct phylogenetic groups, the GI-1 lineage which contains classical strains and the GI-23 lineage that contains field IBV variants which was further sub-divided into Egy/var I and Egy/var II which are related to IS/1494 and IS/885 (Abdel-Moneim et al., 2002; Abdel-Moneim et al., 2012; Zanaty et al., 2016). In spite of this fact, other IBV lineages such as GI-12 (AbdelMoneim et al., 2006; Valastro et al., 2016), GI-13 (Rohaim et al., 2019) and GI-16 (Q1 like strains) (Kiss et al., 2016; Abdel-Sabour et al., 2017) have been reported in Egypt.

Although chicken flocks are routinely vaccinated with live attenuated vaccines, outbreaks of IB in vaccinated flocks have been occurred, since there is little or no cross-protection among various serotypes of IBV (Reddy et al., 2015). The present study provided a monitoring data regarding the molecular characteristics, evolutionary relationship and genetic diversity of IBV strains isolated from chickens in Qena province as one of the southern provinces of Egypt in view of the fact that the majority of scientific research in Egypt focused on studying the IBV in the north and middle of Egypt.

\section{MATERIAL AND METHODS}

\section{Ethical approval}

This research did not involve the introduction of any intervention in/on birds, but the direct collection of tissue samples from freshly dead birds was conducted in full compliance with the recommendations of Faculty of Veterinary Medicine, South Valley University, Qena, Egypt for the care and use of laboratory animals.

\section{Sampling and flocks' history}

Fifty-two tissue samples (lung, trachea, and kidneys) were collected during the period from 2017 to 2019 from nine broiler chicken flocks in Qena province, South Egypt. These flocks were suspected of being infected with IBV and exhibited IB respiratory manifestations such as nasal discharge, sneezing, coughing, bronchial rales, gasping, tracheitis, airsacculitis, lung congestion, caseous materials in the trachea and/or nephropathogenic lesions such as pale enlarged kidneys with prominent tubular pattern. Most of these flocks had been previously vaccinated against IBV with one or more of vaccines of H120, H120
+ D274, 1/96 and M41. The collected samples were labeled, stored on ice, transported to the Poultry Disease Department laboratory, Faculty of Veterinary Medicine, South Valley University, Egypt where kept frozen at -80 ${ }^{\circ} \mathrm{C}$ for further processing.

\section{Egg inoculation and virus isolation}

Collected tissue samples from each IBV-suspected flocks were homogenized in PBS $(10 \% \mathrm{w} / \mathrm{v})$ containing 5,000 IU $/ \mathrm{ml}$ penicillin $\mathrm{G}, 5 \mu \mathrm{g} / \mathrm{ml}$ amphotericin $\mathrm{B}$, and 5 $\mathrm{mg} / \mathrm{ml}$ streptomycin (Sigma Chemical Co., USA). The homogenates were then centrifuged at $3000 \mathrm{rpm}$ for 10 min after incubation at $4{ }^{\circ} \mathrm{C}$ overnight and then $200 \mathrm{ul}$ of the supernatant from each sample was inoculated into three 9-11-day-old embryonated chicken eggs. The allantoic fluid was harvested at 5-7 days post-inoculation and used for subsequent passages. The embryos were evaluated for gross lesions at each passage and this was performed as described by Guy (2008).

\section{RNA extraction and real-time reverse transcriptase PCR}

The genomic viral RNA of 52 samples were extracted from the harvested infected allantoic fluid using QIAmp ${ }^{\circledR}$ Viral RNA Mini Kit (Qiagen, Valencia, CA, USA) according to the manufacturer's protocol. Presence of IBV in all samples was checked by rRT-PCR targeting the $\mathrm{N}$ gene of IBV using QuantiTect ${ }^{\circledR}$ probe RT-PCR kits (Qiagen, Hilden, Germany), and the reactions were carried out on Agilent Mx3005P thermocycler machine (Life Technologies, USA) using two specific primers, (AIBVfr): 5'- ATG CTC AAC CTT GTC CCT AGC A -3' and (AIBV-as) 5'- TCA AAC TGC GGA TCA TCA CGT -3' and probe (AIBV-TM) 5'- [FAM] TTG GAA GTA GAG TGA CGC CCA AAC TTC A [TAMRA] -3' to amplify a $130 \mathrm{bp}$ fragment of $\mathrm{N}$ gene as previously described by Meir et al. (2010) in the following conditions: $50{ }^{\circ} \mathrm{C}$ for 30 min, one cycle at $95{ }^{\circ} \mathrm{C}$ for $15 \mathrm{~min}$, followed by 40 cycles at $95{ }^{\circ} \mathrm{C}$ for $15 \mathrm{sec}$ and $60{ }^{\circ} \mathrm{C}$ for $45 \mathrm{sec}$.

\section{Reverse transcriptase PCR and full S1 sequencing} RT-PCR was performed to amplify the full S1 gene using Qiagen one step RT-PCR kit (Qiagen, Valencia, CA, USA) according to the manufacturer's protocol, using two specific primer pair sets (Table 1) in two overlapping PCR fragments. The RT- PCR using the first primer pair was performed under the following conditions: $50^{\circ} \mathrm{C}$ for 30 min, then $95^{\circ} \mathrm{C}$ for $15 \mathrm{~min}, 35$ cycles $\left(94^{\circ} \mathrm{C}\right.$ for $1 \mathrm{~min}$, $54^{\circ} \mathrm{C}$ for $45 \mathrm{~s}, 72^{\circ} \mathrm{C}$ for $\left.1 \mathrm{~min}\right), 72^{\circ} \mathrm{C}$ for $10 \mathrm{~min}$, while the same conditions were used with the second primer pair except the number of cycles were 40 cycles and the extension time changed to be $72^{\circ} \mathrm{C}$ for $1.30 \mathrm{~min}$. The PCR product was analyzed by electrophoresis on $1.2 \%$ agarose gel stained with SYBR Green and visualized using an ultraviolet transilluminator. After gel electrophoresis confirmation, the PCR products were sent for sequencing by a commercial service provider (Macrogen, Inc., South 
Korea) where the PCR products were purified and sequenced in both forward and reverse directions using the same primer pair sets.

Table 1. Primers used in this study to amplify the fulllength spike glycoprotein (S1) gene

\begin{tabular}{ccccc}
\hline Name & Sequence (5'-3') & $\begin{array}{c}\text { Band size } \\
\text { (base pair) }\end{array}$ & Reference \\
\hline SF 1-1 & GCCAGTTGTTAATTTGAAAAC & \multirow{2}{*}{980} & (Pohuang et al., \\
\cline { 1 - 2 } SR 1-1 & TAATAACCACTCTGAGCTGT & & 2011; Yousefi \\
et al., 2019)
\end{tabular}

Sequence analysis and phylogenetic analysis

All chromatograms were analyzed, assembled using DNA Baser Assembler v5.15.0 software. The sequences obtained in the current study together with the other representative IBV sequences obtained from NCBI GenBank $(n=106)$ were aligned based on the nucleotide sequences with MUSCLE criterion (Edgar, 2004), implemented in MEGA6 software (Tamura et al., 2013). Prior to phylogenetic analysis, Gblocks software (Talavera and Castresana, 2007) was used to remove all potentially poorly aligned regions. For this analysis, a less stringent procedure, allowing for gap positions within final blocks, was applied. The phylogenetic analysis based on the full S1 gene was carried out with MEGA6 software using Maximum likelihood method with the general time reversible model as implemented in MEGA6 and a discrete gamma distribution with 1000 bootstrap replicates (Felsenstein, 1985) was used in the data analysis to assess the robustness of the branches. Evolutionary distances between the studied sequences and the reference and vaccine strains were inferred using the full S1 dataset, with pairwise comparisons of nucleotide sequences performed using BioEdit software v7.0.5.3 (Hall, 1999). Multiple alignment of deduced amino acid sequences with the amino acid sequences of the most currently used vaccine strains in Egypt was carried out using BioEdit software v7.0.5.3 (Hall, 1999). The nucleotide sequences obtained in this study were submitted to the NCBI GenBank to assign accession numbers (Table 2).

\section{RESULTS AND DISCUSSION}

\section{Virus isolation and identification}

Similar to other RNA viruses, the IBV virus is constantly evolving and mutating (Jackwood, 2012). Studies of genetic diversity and the relationships among other viruses circulating globally are very important for tracking the circulation of viruses and for better understanding of how isolates evolve to give rise to new variants of IBV. In this study, inoculation of collected tissue samples in embryonated chicken eggs revealed the ability of many isolated samples to induce typical IBV lesions such as stunting, curling, dwarfing, abnormal feathering and subcutaneous congestion (De Wit, 2000; Guy, 2008) in some inoculated embryos. Testing of harvested allantoic fluids for IBV by using rRT-PCR assay revealed that 29 out of 52 samples were positive for IBV and 9 out of 29 positive samples were selected to be amplified with one-step RT- PCR assay for full S1 sequencing and genetic characterization (Table 2).

\section{Distance and phylogenetic analysis of full-length S1 gene}

Recently, genetic characterization based on the full S1 gene of IBV has become the primary method for classifying IBV strains because of its functional significance and heterogenicity (Valastro et al., 2016). The phylogenetic analysis based on the full $\mathrm{S} 1$ sequences representing different IBV strains $(n=106)$ demonstrated that all nine isolates in this current study were variants and none of them were classic or of vaccine origin. One of those nine isolates named (IBV/CK/EG/QENA-4/2017) clustered with other isolates from Italy, China, South Korea, Taiwan, Vietnam, and Peru in GI-16 (Valastro et al., 2016) (Figure 1). Interestingly, this isolate, which was isolated from a unvaccinated broiler flock, was very closely related to other strains isolated in China (GU938413.1, HM363027.1, AF286302.1 and AF286303.1), Italy (KP780179.1) and Vietnam (KY992863.1) (Yu et al., 2001; Zou et al., 2010; Ji et al., 2011; Franzo et al., 2015; Le et al., 2019) and showed high levels of nucleotide (99.7-99.9\%) and deduced amino acid (99.2-99.8\%) identities. These very high identities based on the nucleotide and amino acid sequences with other viruses indicate a common origin among these viruses.

The GI-16 lineage previously identified as Q1-like IBV or $\mathrm{CK} / \mathrm{CH} / \mathrm{LDL} / 97 \mathrm{I}$-type IBV was first identified in China in 1995 from layer flock with proventriculitis (Yu et al., 2001). The strains of this lineage were isolated regularly from both vaccinated and non-vaccinated chicken flocks (Yu et al., 2001; Luo et al., 2012). Also, in 2011, the GI-16 lineage was isolated from three different Middle Eastern countries (Jordan, Saudi Arabia, and Iraq) from chicken flocks suffered from respiratory manifestations, kidney affections and decrease in egg production (Ababneh et al., 2012), and in Egypt, the strains of this lineage were isolated from broiler flocks suffered from respiratory symptoms associated with renal lesions and increased mortality (Kiss et al., 2016; AbdelSabour et al., 2017). 
The remaining eight isolates were clustered together in a separate monophyletic branch within GI-23 (Valastro et al., 2016) (Figure 1), suggesting that IBV circulating in this area is undergoing evolution. These eight variant isolates were found to be highly related among themselves with 95.4-99.9\% and 94.1-99.8\% nucleotide and amino acid sequence identities, respectively (Table 3). The percentage of the nucleotide and amino acid sequence identities (87.49-93.9\% and 81.2-92.2\%, respectively) among these eight isolates and the rest of the GI-23 viruses used in the construction of the phylogenetic tree showed higher nucleotide and amino acid diversity within the lineage.

GI-23 lineage of IBV was first recognized in Israel in 1998 from chickens suffering from respiratory and kidney lesions (Meir et al., 2004; Valastro et al., 2016) then spread rapidly to Egypt and other Middle East countries. For nearly 20 years, the strains of GI-23 have been geographically limited to Middle East countries, but have recently spread to some European countries (Valastro et al., 2016; Lisowska et al., 2017; Fischer et al., 2019). In Egypt, GI-23 lineage has become the most prevalent lineage in the field as the majority of circulating IBV variant strains reported in chickens belong to this lineage as stated in many studies (Awad et al., 2014; Valastro et al., 2016; Zanaty et al., 2016; Abdel-Sabour et al., 2017; Abozeid et al., 2017; Naguib et al., 2017), Which is consistent with the results obtained in this study.

Compared to the commonly used vaccine strains in Egypt, the nine isolates in this study showed different levels of nucleotide (77.4-82.3\%) and amino acid (74.2$81.8 \%$ ) identities to the H120, Ma5, Mass41, 4/91, CR88, D274 and Israel variant 1(1/96) strains. The vaccine strain D274 shared the highest nucleotide amino acid identities among the vaccine strains with isolates obtained in this study. In addition to the pairwise identity, the phylogenetic analysis revealed that these nine variant isolates had a far distant relation to these vaccine strains. The high sequence differences between our isolates and the commonly used vaccine strains in Egypt may explain the reason for the failure of the vaccines to protect against challenge with these field strains.

On the other hand, there are other factors should be taken in consideration such as immunocompromised chicken flocks with other pathogens (Cheng et al., 2018), lack of bio-security (Jackwood and Lee, 2017) as well as the improper application of vaccines (Magouz et al., 2018). However, the frequent evolution of novel IBV variants is still the main cause of vaccination failure (Reddy et al., 2015; Khataby et al., 2016).

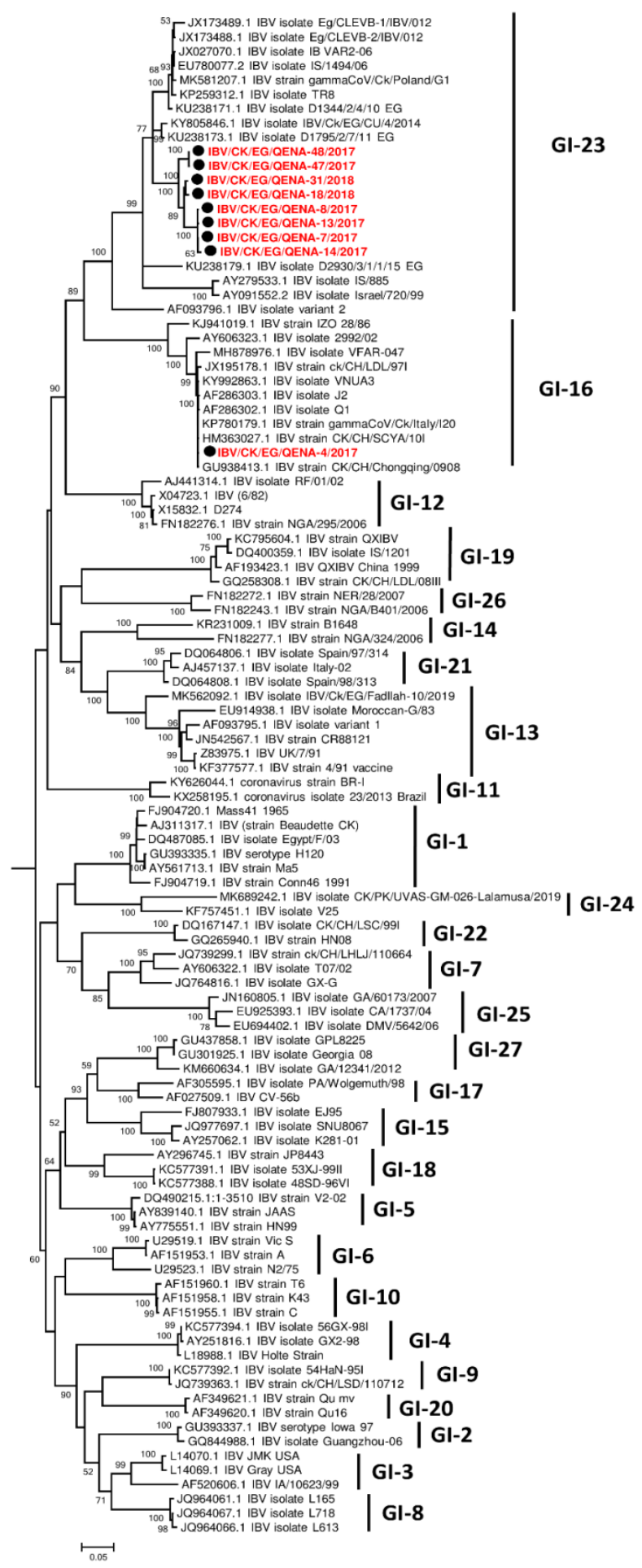

Figure 1. Phylogenetic analysis based on a full-length nucleotide sequence of the S1 gene, showing the relationship among the isolates in this study and other infectious bronchitis virus strains retrieved from Genbank. The tree was constructed using the maximum-likelihood method with $(\mathrm{GTR}+\mathrm{G}+\mathrm{I})$ model and 1000 bootstrap replicates using MEGA 6 software. There were a total of 1570 positions in the final dataset. The isolates sequenced in this study are highlighted in bold font with red color. 
Table 2. Flocks data sampled for infectious bronchitis virus isolates used for full-length spike glycoprotein (S1) gene characterization

\begin{tabular}{|c|c|c|c|c|c|c|c|}
\hline No. & Isolate identification & $\begin{array}{l}\text { Flock age } \\
\text { (day) }\end{array}$ & $\begin{array}{c}\text { Vaccines used in } \\
\text { flock against } \\
\text { infectious bronchitis }\end{array}$ & $\begin{array}{l}\text { Collection } \\
\text { date }\end{array}$ & Flock location & Signs and postmortem lesions & Accession No. \\
\hline 1 & IBV/CK/EG/QENA-4/2017 & 29 & Non vaccinated & November 2017 & Qena- Dishna & Sever respiratory manifestations & MN890126 \\
\hline 2 & IBV/CK/EG/QENA-7/2017 & 29 & M41 & September 2017 & Qena- Abu Tesht & $\begin{array}{l}\text { Kidney damage with high morbidity } \\
\text { and mortality rates }\end{array}$ & MN890127 \\
\hline 3 & IBV/CK/EG/QENA-8/2017 & 29 & M41 & September 2017 & Qena- Abu Tesht & $\begin{array}{l}\text { Kidney damage with high morbidity } \\
\text { and mortality rates }\end{array}$ & MN890128 \\
\hline 4 & IBV/CK/EG/QENA-13/2017 & 29 & M41 & September 2017 & Qena- Abu Tesht & $\begin{array}{l}\text { Kidney damage with high morbidity } \\
\text { and mortality rates }\end{array}$ & MN890129 \\
\hline 5 & IBV/CK/EG/QENA-14/2017 & 29 & M41 & September 2017 & Qena- Abu Tesht & $\begin{array}{l}\text { Kidney damage with high morbidity } \\
\text { and mortality rates }\end{array}$ & MN890130 \\
\hline 6 & IBV/CK/EG/QENA-18/2018 & 17 & H120 & March 2018 & Qena- Dishna & Sever respiratory manifestations & MN890131 \\
\hline 7 & IBV/CK/EG/QENA-31/2018 & 32 & H120 \& 1/96 & December 2018 & Qena- Qus & Sever respiratory manifestations & MN890132 \\
\hline 8 & IBV/CK/EG/QENA-47/2017 & 32 & $\mathrm{H} 120$ + D274 & December 2017 & Qena- Abu Tesht & $\begin{array}{l}\text { Kidney damage with high morbidity } \\
\text { and mortality rates }\end{array}$ & MN890133 \\
\hline 9 & IBV/CK/EG/QENA-48/2017 & 32 & $\mathrm{H} 120$ + D274 & December 2017 & Qena- Abu Tesht & $\begin{array}{l}\text { Kidney damage with high morbidity } \\
\text { and mortality rates }\end{array}$ & MN890134 \\
\hline
\end{tabular}


Table 3. Nucleotide and amino acid identities of full-length spike glycoprotein (S1) gene sequence of the nine infectious bronchitis virus isolates in this study with other Egyptian strains, reference strains and vaccine strains.

\begin{tabular}{|c|c|c|c|c|c|c|c|c|c|c|c|c|c|c|c|c|c|c|c|c|c|c|}
\hline \multicolumn{23}{|c|}{ Amino acid identity (\%) } \\
\hline & & 1 & 2 & 3 & 4 & 5 & 6 & 7 & 8 & 9 & 10 & 11 & 12 & 13 & 14 & 15 & 16 & 17 & 18 & 19 & 20 & \\
\hline 1 & GU393335.1_H120 & & 99.8 & 96.4 & 78.6 & 75.4 & 75.0 & 75.2 & 75.9 & 77.5 & 76.3 & 75.8 & 75.8 & 75.8 & 75.9 & 75.6 & 75.0 & 75.4 & 75.8 & 75.4 & 75.6 & 1 \\
\hline 2 & AY561713.1_Ma5 & 99.8 & & 96.2 & 78.4 & 75.2 & 74.8 & 75.0 & 75.9 & 77.5 & 76.3 & 75.6 & 75.6 & 75.8 & 75.9 & 75.6 & 75.0 & 75.4 & 75.8 & 75.4 & 75.6 & 2 \\
\hline 3 & FJ904720.1_Mass41_1965 & 97.6 & 97.7 & & 77.8 & 74.8 & 74.2 & 74.6 & 74.8 & 76.7 & 75.6 & 75.4 & 75.4 & 75.0 & 74.8 & 74.8 & 74.2 & 74.6 & 75.0 & 74.6 & 74.8 & 3 \\
\hline 4 & X15832.1_D274 & 80.9 & 80.9 & 80.6 & & 80.1 & 79.0 & 78.6 & 79.3 & 82.9 & 83.5 & 81.4 & 81.6 & 81.8 & 81.6 & 81.4 & 81.0 & 81.2 & 81.4 & 81.4 & 81.6 & 4 \\
\hline 5 & JN542567.1_CR88121 & 78.1 & 78.0 & 78.4 & 79.6 & & 93.1 & 95.4 & 76.7 & 79.0 & 80.3 & 77.8 & 77.8 & 80.3 & 79.9 & 79.7 & 79.3 & 79.0 & 79.2 & 79.0 & 79.2 & 5 \\
\hline 6 & KF377577.1_4/91 & 78.6 & 78.6 & 78.9 & 79.1 & 96.6 & & 92.2 & 77.5 & 77.6 & 79.2 & 77.3 & 77.3 & 79.5 & 79.5 & 79.3 & 78.4 & 78.0 & 78.6 & 78.0 & 78.2 & 6 \\
\hline 7 & AF093795.1/IS variant1 (1/96) & 78.0 & 78.0 & 78.3 & 79.4 & 97.4 & 95.5 & & 76.9 & 78.8 & 79.3 & 77.6 & 77.6 & 79.7 & 79.7 & 79.5 & 78.6 & 78.6 & 78.8 & 78.6 & 78.8 & 7 \\
\hline 8 & AY279533.1_IS/885_S1 & 78.6 & 78.6 & 78.6 & 78.9 & 77.9 & 78.6 & 77.7 & & 87.9 & 87.9 & 79.7 & 79.7 & 87.1 & 87.1 & 86.7 & 86.2 & 86.0 & 86.7 & 86.3 & 86.5 & 8 \\
\hline 9 & KY805846.1 EG/CU/4/2014 & 80.3 & 80.1 & 80.3 & 82.8 & 78.8 & 78.5 & 79.0 & 88.4 & & 94.5 & 81.6 & 81.8 & 91.6 & 91.3 & 91.1 & 90.7 & 92.4 & 92.0 & 92.4 & 92.6 & 9 \\
\hline 10 & EU780077.2_IS/1494/06 & 80.1 & 79.9 & 79.9 & 83.1 & 79.2 & 79.2 & 79.2 & 88.1 & 95.4 & & 82.0 & 82.2 & 91.4 & 91.1 & 90.9 & 90.5 & 91.8 & 91.8 & 91.8 & 92.0 & 10 \\
\hline 11 & AF286302.1_Q1 & 77.5 & 77.4 & 78.1 & 80.7 & 78.6 & 78.8 & 78.9 & 80.1 & 82.1 & 81.6 & & 99.6 & 82.4 & 82.4 & 82.0 & 81.8 & 80.9 & 81.2 & 82.4 & 82.6 & 11 \\
\hline 12 & IBV/CK/EG/QENA-4/2017 & 77.5 & 77.4 & 78.1 & 80.6 & 78.6 & 78.8 & 78.9 & 80.2 & 82.2 & 81.6 & 99.8 & & 82.4 & 82.4 & 82.0 & 81.8 & 81.0 & 81.4 & 82.6 & 82.7 & 12 \\
\hline 13 & IBV/CK/EG/QENA-7/2017 & 79.6 & 79.4 & 79.6 & 82.3 & 79.1 & 79.4 & 79.0 & 87.4 & 92.3 & 92.6 & 81.5 & 81.5 & & 99.6 & 99.4 & 98.8 & 96.5 & 96.9 & 95.2 & 95.4 & 13 \\
\hline 14 & IBV/CK/EG/QENA-8/2017 & 79.7 & 79.5 & 79.6 & 82.1 & 79.0 & 79.4 & 79.0 & 87.4 & 92.2 & 92.5 & 81.4 & 81.4 & 99.8 & & 99.4 & 98.4 & 96.7 & 97.1 & 94.8 & 95.0 & 14 \\
\hline 15 & IBV/CK/EG/QENA-13/2017 & 79.5 & 79.3 & 79.5 & 82.1 & 78.9 & 79.3 & 78.9 & 87.3 & 92.1 & 92.5 & 81.3 & 81.3 & 99.8 & 99.8 & & 98.2 & 96.4 & 96.7 & 94.7 & 94.8 & 15 \\
\hline 16 & IBV/CK/EG/QENA-14/2017 & 79.2 & 79.0 & 79.2 & 82.0 & 78.8 & 79.1 & 78.7 & 87.0 & 91.9 & 92.2 & 81.1 & 81.1 & 99.5 & 99.4 & 99.3 & & 95.4 & 95.8 & 94.1 & 94.3 & 16 \\
\hline 17 & IBV/CK/EG/QENA-18/2018 & 79.6 & 79.4 & 79.6 & 82.0 & 79.0 & 78.9 & 78.9 & 87.4 & 93.6 & 93.4 & 81.4 & 81.4 & 97.1 & 97.2 & 97.1 & 96.7 & & 99.2 & 96.2 & 96.4 & 17 \\
\hline 18 & IBV/CK/EG/QENA-31/2018 & 79.7 & 79.5 & 79.7 & 81.9 & 78.8 & 78.9 & 78.7 & 87.6 & 93.6 & 93.5 & 81.3 & 81.3 & 97.2 & 97.3 & 97.2 & 96.8 & 99.3 & & 96.2 & 96.4 & 18 \\
\hline 19 & IBV/CK/EG/QENA-47/2017 & 79.4 & 79.3 & 79.4 & 82.2 & 78.9 & 78.9 & 78.8 & 87.2 & 93.7 & 93.0 & 82.0 & 82.1 & 95.8 & 95.7 & 95.6 & 95.4 & 97.4 & 97.2 & & 99.8 & 19 \\
\hline \multirow[t]{2}{*}{20} & IBV/CK/EG/QENA-48/2017 & 79.4 & 79.4 & 79.5 & 82.3 & 79.0 & 78.9 & 78.9 & 87.2 & 93.7 & 93.0 & 82.1 & 82.1 & 95.9 & 95.7 & 95.7 & 95.4 & 97.4 & 97.3 & 99.9 & & 20 \\
\hline & & 1 & 2 & 3 & 4 & 5 & 6 & 7 & 8 & 9 & 10 & 11 & 12 & 13 & 14 & 15 & 16 & 17 & 18 & 19 & 20 & \\
\hline \multicolumn{23}{|c|}{ Nucleotide identity (\%) } \\
\hline
\end{tabular}




\begin{tabular}{|c|c|c|}
\hline \multicolumn{2}{|r|}{ HVR1 } & HVR2 \\
\hline & 50 & 140 \\
\hline & $\ldots|\ldots| \ldots|\ldots| \ldots|\ldots| \ldots$ & $\ldots|\ldots| \ldots|\ldots| \ldots|\ldots| \ldots|\ldots| \ldots|\ldots| \ldots|\ldots|$ \\
\hline GU393335. 1 H120 & DGWHLHGGAYAVVNISSESNNAGSSSGCTV & AWSSSQFCTAYCNFSDTTVEVTHCYKH--GGCPITGMLQOHSIRVSAMKNG \\
\hline AY561713.1 Ma5 & 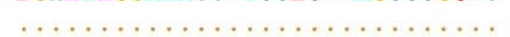 & 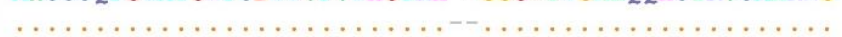 \\
\hline FJ904720.1_Mass41_1965 & N. $\ldots \ldots \ldots \ldots \ldots \ldots \ldots$ P..I. & 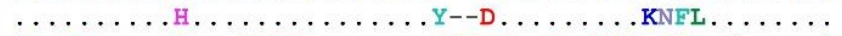 \\
\hline $\mathrm{X} 15832.1 \_\mathrm{D} \overline{2} 74$ & 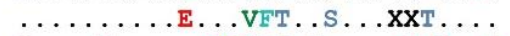 & 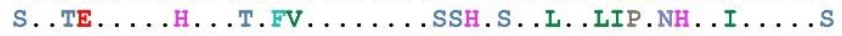 \\
\hline JN542567.1_CR88121 & P...Y..... DRVEN.T. . . A.D..A & 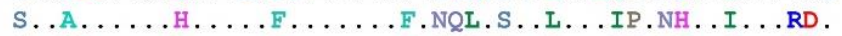 \\
\hline $\mathrm{KF} 377577.1^{-} 4 / 91$ & Q........DKVENGT...V.V.D..A & 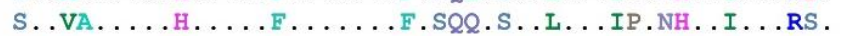 \\
\hline AF093795.1_Is variant1 $(1 / 96)$ & S...I....... DRVEN.T.....V.D..A & S. V. \\
\hline IBV/CK/EG/QENA-4/2017 & $\ldots \ldots \ldots \ldots$ V.I.T. . . TA. . IA & 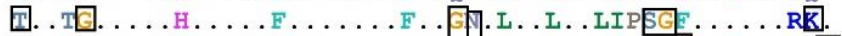 \\
\hline IBV/CK/EG/QENA-7/2017 & 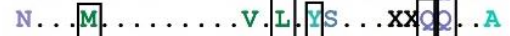 & 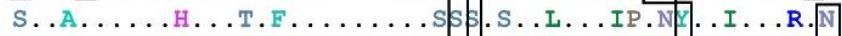 \\
\hline IBV/CK/EG/QENA-8/2017 & $\mathrm{N} \ldots \mathrm{M} . \ldots \ldots \mathrm{V} \cdot \mathrm{I}$. $\mathrm{s} \ldots \mathrm{xx}$ क. . A & s..va \\
\hline IBV/CK/EG/QENA-13/2017 & 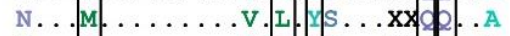 & 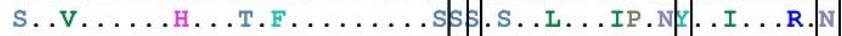 \\
\hline IBV/CK/EG/QENA-14/2017 & $\mathrm{N} \ldots \mathrm{M}, \ldots \ldots \mathrm{V} \cdot \mathrm{I}$. $\mathrm{s} \ldots \mathrm{xx}$ क & S. А $\ldots$ нв \\
\hline IBV/CK/EG/QENA-18/2018 & 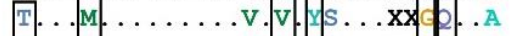 & 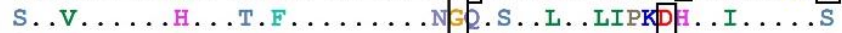 \\
\hline IBV/CK/EG/QENA-31/2018 & $\mathrm{T} \ldots \mathrm{M} . \ldots \ldots \mathrm{v} \cdot \mathrm{v} \cdot \mathrm{s} \ldots \mathrm{xx}$. . A & 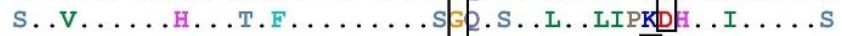 \\
\hline IBV/CK/EG/QENA-47/2017 & $\mathrm{T} \ldots \mathrm{M} . \ldots \ldots \mathrm{V} \cdot \mathrm{v} \cdot \mathrm{s} \ldots \mathrm{xx}$.. $\mathrm{A}$ & 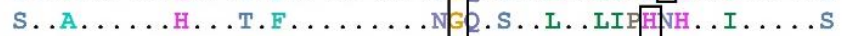 \\
\hline IBV/CK/EG/QENA-48/2017 & 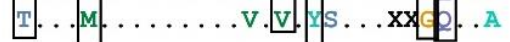 & 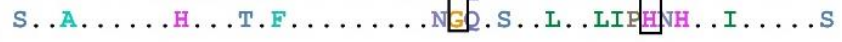 \\
\hline
\end{tabular}

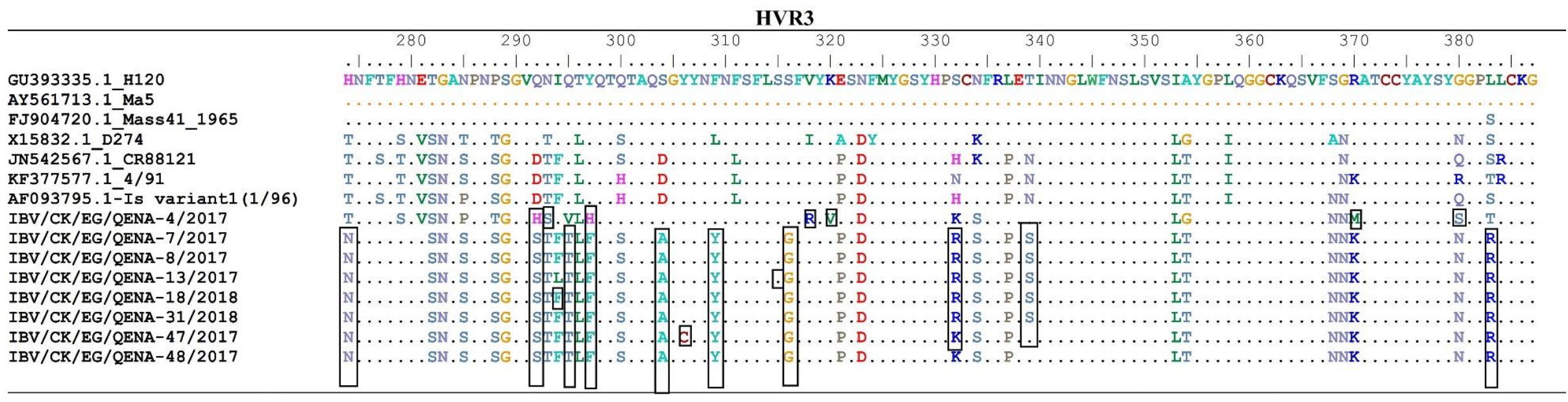

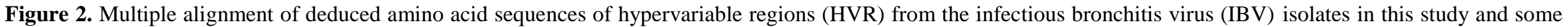

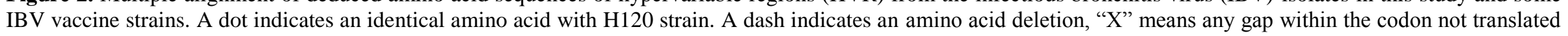
to a valid amino acid. 


\section{Alignment analysis of deduced amino acid}

The S1 protein contains three HVRs associated with serotype specificity and virus-neutralizing epitopes and located within the amino acid residues 38-67, 91-141, and 274-387 (Moore et al., 1997; Wang and Huang, 2000). In this study, full-length $\mathrm{S} 1$ gene sequences of obtained isolates were translated and aligned with the amino acid sequences of the most currently used vaccine strains in Egypt. Based on the alignment in three HVRs of S1, the nine isolates showed unique amino acid differences in comparison to the commonly used vaccine strains (Figure 2). It is well known that even small changes in the amino acid sequence of the spike protein can contribute to the generation of new antigenic types that can alter the protective ability of a vaccine (Adzhar et al., 1997; Casais et al., 2003).

\section{CONCLUSION}

The present study provided a robust depiction of genetic characteristics of IBVs isolated from chickens in Qena province, Egypt as well as the evidence for the emergence of IBV variants in vaccinated and unvaccinated broiler flocks. This study demonstrated the circulation of two IBV variants lineages (GI-16 and GI-23). The genetic variability among studied isolates and commonly used vaccine strains can explain the poor vaccination performance and disease outbreak in this region. The continuous disease monitoring and surveillance are required not only to elucidate sequence characteristics of prevailing strains but also to revise appropriate vaccine strategies. These data will be essential as a step for selecting appropriate vaccine strains as well as planning for future vaccine strategies.

\section{DECLARATIONS}

\section{Authors' contributions}

All authors contributed equally to this work.

\section{Competing interests}

The authors declare that there is no competing of interests.

\section{Acknowledgments}

The authors would like to acknowledge the Scientific Research Administration, South Valley University, Egypt for funding this study.

\section{REFERENCES}

Ababneh M, Dalab AE, Alsaad S and Al-Zghoul M (2012). Presence of infectious bronchitis virus strain CK/CH/LDL/97I in the Middle East. ISRN Veterinary Science, 2012: 201721. DOI: https://doi.org/10.5402/2012/201721

Abdel-Moneim AS, El-Kady MF, Ladman BS and Gelb J (2006). S1 gene sequence analysis of a nephropathogenic strain of avian infectious bronchitis virus in Egypt. Virology journal, 3: 78. DOI: https://doi.org/10.1186/1743-422X-3-78

Abdel-Moneim AS, Madbouly H, Gelb J and Ladman B (2002). Isolation and identification of Egypt/Beni-Seuf/01 a novel genotype of infectious bronchitis virus. Veterinary Medical Journal-Giza, 50(4): 1065-1078. Available at: https://www.researchgate.net/publication/257856074_

Abdel-Sabour MA, Al-Ebshahy EM, Khaliel SA, Abdel-Wanis NA and Yanai T (2017). Isolation and molecular characterization of novel infectious bronchitis virus variants from vaccinated broiler flocks in Egypt. Avian Diseases, 61(3): 307-310. DOI: https://doi.org/10.1637/11566-121516-RegR

Abozeid HH, Paldurai A, Khattar SK, Afifi MA, El-Kady MF, El-Deeb AH and Samal SK (2017). Complete genome sequences of two avian infectious bronchitis viruses isolated in Egypt: Evidence for genetic drift and genetic recombination in the circulating viruses. Infection, Genetics and Evolution, 53: 7-14. DOI: https://doi.org/10.1016/j.meegid.2017.05.006

Adzhar A, Gough R, Haydon D, Shaw K, Britton P and Cavanagh D (1997). Molecular analysis of the 793/B serotype of infectious bronchitis virus in Great Britain. Avian Pathology, 26(3): 625-640. DOI: https://doi.org/10.1080/03079459708419239

Ahmed H (1954). Incidence and treatment of some infectious viral respiratory diseases of poultry in Egypt. DVM Thesis. Cairo University, Cairo, Egypt.

Awad. AM, Sediek ME and El-Yamany ME (2014). Isolation and molecular characterization of novel IBV isolates from broiler chicken farms in Egypt. Alexandria Journal of Veterinary Sciences, 42(1): 74-82. DOI: https://doi.org/10.5455/ajvs.160278

Bande F, Arshad SS, Omar AR, Bejo MH, Abubakar MS and Abba Y (2016). Pathogenesis and diagnostic approaches of avian infectious bronchitis. Advances in Virology, 2016. DOI: https://doi.org/10.1155/2016/4621659

Boursnell MEG, Brown TDK, Foulds IJ, Green PF, Tomley FM and Binns MM (1987). Completion of the sequence of the genome of the coronavirus avian infectious bronchitis virus. Journal of General Virology, 68(1): 57-77. DOI: https://doi.org/10.1099/0022-1317$68-1-57$

Casais R, Dove B, Cavanagh D and Britton P (2003). Recombinant avian infectious bronchitis virus expressing a heterologous spike gene demonstrates that the spike protein is a determinant of cell tropism. Journal of Virology, 77(16): 9084-9089. DOI: https://doi.org/10.1128/JVI.77.16.9084-9089.2003

Cavanagh D (2007). Coronavirus avian infectious bronchitis virus. Veterinary Research, 38(2): 281-297. DOI: https://doi.org/10.1051/vetres:2006055

Cavanagh D, Davis PJ and Mockett APA (1988). Amino acids within hypervariable region 1 of avian coronavirus IBV (Massachusetts serotype) spike glycoprotein are associated with neutralization 
epitopes. Virus Research, 11(2): 141-150. DOI: https://doi.org/10.1016/0168-1702(88)90039-1

Cavanagh D and Gelb J (2008). Infectious Bronchitis. In YM Saif (Editor.), Diseases of poultry. 12th Edition. Ames, Iowa Blackwell, Iowa State University Press. pp. 117-135.

Cheng J, Huo C, Zhao J, Liu T, Li X, Yan S, Wang Z, Hu Y and Zhang G (2018). Pathogenicity differences between QX-like and Masstype infectious bronchitis viruses. Veterinary Microbiology, 213: 129-135. DOI: https://doi.org/10.1016/j.vetmic.2017.11.027

De Wit J, Cook JK, Van der Heijden and MJF H (2011). Infectious bronchitis virus variants: a review of the history, current situation and control measures. Avian Pathology, 40(3): 223-235. DOI: https://doi.org/10.1080/03079457.2011.566260

De Wit JJ (2000). Detection of infectious bronchitis virus. Avian $\begin{array}{llll}\text { Pathology, } & 29(2) \text { : } & \text { 71-93. }\end{array}$ https://doi.org/10.1080/03079450094108

Edgar RC (2004). MUSCLE: Multiple sequence alignment with high accuracy and high throughput. Nucleic Acids Research, 32(5): 1792-1797. DOI: https://doi.org/10.1093/nar/gkh340

Felsenstein J (1985). Confidence limits on phylogenies: an approach using the bootstrap. Evolution, 39(4): 783-791. DOI: https://doi.org/10.2307/2408678

Fischer S, Klosterhalfen D, Wilms-Schulze Kump F and Casteel M (2019). Research Note: First evidence of infectious bronchitis virus Middle-East GI-23 lineage (Var2-like) in Germany. Poultry $\begin{array}{lll}\text { Science, } & \text { 99(2):797-800 DOI: }\end{array}$ https://doi.org/10.1016/j.psj.2019.10.031

Franzo G, Listorti V, Naylor CJ, Lupini C, Laconi A, Felice V, Drigo M, Catelli E and Cecchinato M (2015). Molecular investigation of a full-length genome of a Q1-like IBV strain isolated in Italy in 2013. Virus $\quad$ Research, 210: 77-80. DOI: https://doi.org/10.1016/j.virusres.2015.07.008

Guy JS. (2008). Isolation and propagation of coronaviruses in embryonated eggs. In D Cavanagh (Ed.), SARS- and Other Coronaviruses: Laboratory Protocols. Totowa, NJ, Humana Press. pp. 109-117.

Hall TA (1999). BioEdit: a user-friendly biological sequence alignment editor and analysis program for Windows 95/98/NT. Nucleic Acids Symposium Series, 41: 95-98.

Jackwood MW (2012). Review of infectious bronchitis virus around the world. Avian Diseases, 56(4): 634-641. DOI: https://doi.org/10.1637/10227-043012-Review.1

Jackwood MW and de Wit S. (2013). Infectious bronchitis. In DE Swayne (Editor.), Diseases of poultry. 13th Edition. Hoboken, New Jersey, Wiley Blackwell. pp. 139-159.

Jackwood MW and Lee D-H (2017). Different evolutionary trajectories of vaccine-controlled and non-controlled avian infectious bronchitis viruses in commercial poultry. PloS one, 12(5): e0176709. DOI: https://doi.org/10.1371/journal.pone.0176709

Ji J, Xie J, Chen F, Shu D, Zuo K, Xue C, Qin J, Li H, Bi Y, Ma J and Xie Q (2011). Phylogenetic distribution and predominant genotype of the avian infectious bronchitis virus in China during 2008-2009. Virology Journal, 8(1): 184. DOI: https://doi.org/10.1186/1743422X-8-184

Khataby K, Fellahi S, Loutfi C and Mustapha EM (2016). Avian infectious bronchitis virus in Africa: a review. Veterinary
Quarterly, $\quad 36(2)$ : $\quad 71-75$.

DOI: https://doi.org/10.1080/01652176.2015.1126869

Kiss I, Mató T, Homonnay Z, Tatár-Kis T and Palya V (2016). Successive occurrence of recombinant infectious bronchitis virus strains in restricted area of Middle East. Virus Evolution, 2(2): vew021. DOI: https://doi.org/10.1093/ve/vew021

Le TB, Lee H-J, Le VP and Choi K-S (2019). Multiple genotypes of avian infectious bronchitis virus circulating in Vietnam. Korean Journal of Poultry Science, 46(2): 127-136. DOI: https://doi.org/10.5536/KJPS.2019.46.2.127

Lisowska A, Sajewicz-Krukowska J, Fusaro A, Pikula A and DomanskaBlicharz K (2017). First characterization of a Middle-East GI-23 lineage (Var2-like) of infectious bronchitis virus in Europe. Virus Research, 242: 43-48. DOI: https://doi.org/10.1016/j.virusres.2017.09.010

Luo H, Qin J, Chen F, Xie Q, Bi Y, Cao Y and Xue C (2012). Phylogenetic analysis of the S1 glycoprotein gene of infectious bronchitis viruses isolated in China during 2009-2010. Virus Genes, 44(1): 19-23. DOI: https://doi.org/10.1007/s11262-011-0657-x

Magouz A, Abdo W, Abdelsabour A, Elbestawy A and Desouky A (2018). Molecular and histopathological investigation of avian infectious bronchitis virus in the Delta of Egypt between 2016 and 2017. Pakistan Veterinary Journal, 38(3). DOI: http://www.pvj.com.pk/pdf-files/38_3/243-248.pdf

Masters PS (2006). The molecular biology of coronaviruses. Advances in Virus Research, 66: 193-292. DOI: https://doi.org/10.1016/S00653527(06)66005-3

Meir R, Maharat O, Farnushi Y and Simanov L (2010). Development of a real-time TaqMan ${ }^{\circledR}$ RT-PCR assay for the detection of infectious bronchitis virus in chickens, and comparison of RT-PCR and virus isolation. Journal of Virological Methods, 163(2): 190-194. DOI: https://doi.org/10.1016/j.jviromet.2009.09.014

Meir R, Rosenblut E, Perl S, Kass N, Ayali G, Hemsani E and Perk S (2004). Identification of a novel nephropathogenic infectious bronchitis virus in Israel. Avian Diseases, 48(3): 635-641. DOI: https://doi.org/10.1637/7107

Moore K, Jackwood M and Hilt D (1997). Identification of amino acids involved in a serotype and neutralization specific epitope within the S1 subunit of avian infectious bronchitis virus. Archives of Virology, 142(11): 2249-2256. https://doi.org/10.1007/s007050050239

Naguib MM, El-Kady MF, Lüschow D, Hassan KE, Arafa A-S, ElZanaty A, Hassan MK, Hafez HM, Grund C and Harder TC (2017). New real time and conventional RT-PCRs for updated molecular diagnosis of infectious bronchitis virus infection (IBV) in chickens in Egypt associated with frequent co-infections with avian influenza and Newcastle disease viruses. Journal of Virological Methods, 245: 19-27. DOI: https://doi.org/10.1016/j.jviromet.2017.02.018

Perlman S and Netland J (2009). Coronaviruses post-SARS: update on replication and pathogenesis. Nature Reviews Microbiology, 7(6): 439-450. DOI: https://doi.org/10.1038/nrmicro2147

Pohuang T, Chansiripornchai N, Tawatsin A and Sasipreeyajan J (2011). Sequence analysis of $\mathrm{S} 1$ genes of infectious bronchitis virus isolated in Thailand during 2008-2009: identification of natural recombination in the field isolates. Virus Genes, 43(2): 254-260. DOI: https://doi.org/10.1007/s11262-011-0635-3 
Raj GD and Jones RC (1997). Infectious bronchitis virus: immunopathogenesis of infection in the chicken. Avian Pathology, 26(4): 677-706. DOI: https://doi.org/10.1080/03079459708419246

Reddy VR, Theuns S, Roukaerts ID, Zeller M, Matthijnssens J and Nauwynck HJ (2015). Genetic characterization of the Belgian nephropathogenic infectious bronchitis virus (NIBV) reference strain B1648. Viruses, 7(8): 4488-4506. DOI: https://doi.org/10.3390/v7082827

Rohaim MA, El Naggar RF, Hamoud MM, Bazid A-HI, Gamal AM, Laban SE, Abdel-Sabour MA, Nasr SA, Zaki MM and Shabbir MZ (2019). Emergence and genetic analysis of variant pathogenic $4 / 91$ (serotype 793/B) infectious bronchitis virus in Egypt during 2019. Virus Genes, 55(5): 720-725. https://doi.org/10.1007/s11262-01901693-9

Spaan W, Cavanagh D and Horzinek MC (1988). Coronaviruses: structure and genome expression. Journal of General Virology, 69(12): 2939-2952. DOI: https://doi.org/10.1099/0022-1317-69-122939

Talavera G and Castresana J (2007). Improvement of phylogenies after removing divergent and ambiguously aligned blocks from protein sequence alignments. Systematic Biology, 56(4): 564-577. DOI: https://doi.org/10.1080/10635150701472164

Tamura K, Stecher G, Peterson D, Filipski A and Kumar S (2013). MEGA6: Molecular evolutionary genetics analysis version 6.0. Molecular Biology and Evolution, 30(12): 2725-2729. DOI: https://doi.org/10.1093/molbev/mst197

Valastro V, Holmes EC, Britton P, Fusaro A, Jackwood MW, Cattoli G and Monne I (2016). S1 gene-based phylogeny of infectious bronchitis virus: An attempt to harmonize virus classification. Infection, Genetics and Evolution, 39: 349-364. DOI: https://doi.org/10.1016/j.meegid.2016.02.015

Wang CH and Huang YC (2000). Relationship between serotypes and genotypes based on the hypervariable region of the $\mathrm{S} 1$ gene of infectious bronchitis virus. Archives of Virology, 145(2): 291-300. DOI: https://doi.org/10.1007/s007050050024

Yousefi Y, Bassami MR, Kalidari GA and Seno MMG (2019). Sequence characterization of full-length S1 gene of infectious bronchitis viruses isolated from poultry farms in Khorasan Razavi, Iran. Turkish Journal of Veterinary and Animal Sciences, 43(2): 235243. DOI: https://dergipark.org.tr/tr/download/article-file/734722

Yu L, Jiang Y, Low S, Wang Z, Nam SJ, Liu W and Kwang J (2001). Characterization of three infectious bronchitis virus isolates from China associated with proventriculus in vaccinated chickens. Avian Diseases, 45(2): 416-424. DOI: https://doi.org/10.2307/1592981

Zanaty A, Naguib MM, El-Husseiny MH, Mady W, Hagag N and Arafa A-S (2016). The sequence of the full spike S1 glycoprotein of infectious bronchitis virus circulating in Egypt reveals evidence of intra-genotypic recombination. Archives of Virology, 161(12): 3583-3587. DOI: https://doi.org/10.1007/s00705-016-3042-1

Zou NL, Zhao FF, Wang YP, Liu P, Cao SJ, Wen XT and Huang Y (2010). Genetic analysis revealed LX4 genotype strains of avian infectious bronchitis virus became predominant in recent years in Sichuan area, China. Virus Genes, 41(2): 202-209. DOI: https://doi.org/10.1007/s11262-010-0500-9 